\title{
HPV Vaccination: Attitude and Knowledge among German Gynecologists
}

\author{
HPV-Impfung: Einstellung und Wissensstand unter Gynäkologen in Deutschland
}

Authors

Affiliation
T. M. Kolben, C. Dannecker, K. Baltateanu, C. Goess, T. Starrach, A. Semmlinger, N. Ditsch, J. Gallwas, S. Mahner, K. Friese, T. Kolben

Department for Obstetrics and Gynecology, University Hospital of Munich, Ludwig-Maximilians-University, Munich, Germany

Key words
HPV
HPV vaccination
Gardasil
Cervarix
Gardasil-9
Schlüsselwörter
- HPV
- HPV-Impfung
Gardasil
- Cervarix
- Gardasil-9

received 21.6.2016 revised 17.7.2016 accepted 18.7.2016

Bibliography

DOI http://dx.doi.org/

10.1055/s-0042-112813

Geburtsh Frauenheilk 2016; 76:

1074-1080 @ Georg Thieme

Verlag KG Stuttgart · New York . ISSN 0016-5751

\section{Correspondence}

\section{Dr. Theresa M. Kolben}

Department for Obstetrics

and Gynecology

Ludwig-Maximilians-University

Marchioninistraße 15

81377 Munich

Germany

Theresa.Kolben@

med.uni-muenchen.de

\section{Abstract \\ $\nabla$}

Purpose: In order to achieve a higher vaccination rate, education on HPV as well as options for prophylaxis performed by doctors is of great importance. One opportunity to increase the protection against HPV would be vaccinating boys. This study evaluated attitude and knowledge among German gynecologists regarding HPV vaccination, especially in boys.

Material and Methods: A questionnaire with 42 questions about demographics, attitude and knowledge about HPV and HPV vaccination was sent to members of the German Society for Gynecology and Obstetrics (DGGG).

Results: 998 out of 6567 addressed gynecologists participated. Knowledge about HPV, associated diseases and possible HPV vaccines was high among participants. The attitude towards vaccination in boys as well as girls was positive. Only $8.2 \%$ refused to vaccinate their sons whereas $2.2 \%$ refused to do this for their daughters. However, only few gynecologists vaccinated their daughters and sons against HPV. Main reason for girls was an age outside of vaccination guidelines; for boys it was the lack of cost coverage.

Conclusion: The willingness of gynecologists to perform HPV vaccination in boys is as high as for girls. However, sons of gynecologists are only rarely vaccinated against HPV. Main reason is the lack of cost coverage. Vaccinating boys could decrease the disease burden in males, as well as protect women by interrupting ways of transmission. Since the main argument against vaccination of boys is only of financial nature, the necessity of a vaccination recommendation for boys needs to be re-evaluated taking into account the cost-reduced 2-dose vaccination scheme.

\section{Zusammenfassung \\ $\nabla$}

Ziel: Zur Erreichung einer höheren Durchimpfungsrate ist die Aufklärung über HPV sowie Möglichkeiten der Prophylaxe durch den Arzt enorm wichtig. Eine Möglichkeit zur Optimierung des Schutzes gegenüber HPV besteht in der Impfung von Jungen. Diese Studie untersucht daher Einstellung und Wissensstand unter Gynäkologen bezüglich der HPV-Impfung insbesondere bei Jungen.

Methoden: Ein Fragebogen mit 42 Fragen zu demografischen Daten sowie Haltung und Wissen über HPV und die HPV-Impfung wurde an Mitglieder der Deutschen Gesellschaft für Gynäkologie und Geburtshilfe (DGGG) versendet.

Ergebnisse: Es beteiligten sich 998 von 6567 angeschriebenen Ärzten. Das Wissen zu HPV, assoziierten Erkrankungen sowie möglichen HPV-Impfungen unter den Teilnehmern war hoch. Es bestand eine hohe Bereitschaft zur Impfung von Mädchen, aber auch hinsichtlich der Impfung von Jungen waren die Befragten positiv gestimmt. Nur 8,2\% der Befragten würde eine HPV-Impfung ihres Sohnes ablehnen, 2,2\% würden dies bei ihren Töchtern tun. Letztlich haben jedoch nur wenige die Impfung bei ihren Töchtern und Söhnen durchgeführt. Hauptgrund bei Mädchen war hierfür ein außerhalb der Impfempfehlung liegendes Alter, bei Jungen die aktuell fehlende Kostenübernahme der Krankenkasse.

Folgerung: Die Bereitschaft unter Gynäkologen, die HPV-Impfung an Männern durchzuführen, ist ähnlich hoch wie bei Frauen. Dennoch sind die Söhne der Befragten eher selten geimpft. Ursächlich ist hauptsächlich die fehlende Kostenübernahme. Eine Impfung von Jungen könnte jedoch die Krankheitslast bei Männern senken und über eine Unterbrechung der Übertragungswege ebenso Frauen schützen. Da das Hauptargument gegen eine Impfung von Jungen lediglich finanzieller Natur ist, sollte, in Anbetracht des kostengünsti- 
geren 2-Dosen-Impfschemas, die Notwendigkeit einer Impfempfehlung für Jungen neu überdacht werden.

\section{Introduction}

$\nabla$

Infection with human papilloma virus (HPV) represents the most common sexually transmitted disease worldwide. More than a hundred types of HPV are identified with subclassification in either low-risk or high-risk types. Low-risk HPV types 6 and 11 cause anogenital warts also known as condylomata acuminata $[1,2]$. HPV high-risk types are associated with a number of malignant diseases, e.g. cervical, vaginal, vulvar, penile, oropharyngeal and anal carcinoma $[3,4]$. Virtually all cases of cervical cancer are attributed to HPV. HPV high-risk types 16 and 18 are responsible for $70-80 \%$ of all cervical cancers [5-7]. The vast majority of sexually active adults (75-80\%) has had an infection with HPV before the age of 50 [8]. To date, the most effective tool against $\mathrm{HPV}$ infection is primary prevention by vaccination. Two vaccines (Gardasil, Merck \& Co. and Cervarix, GlaxoSmithKline) have already demonstrated high efficacy against HPV 16 and 18 associated cancers as well as cervical intraepithelial neoplasia as the precursor lesions of cervical cancer [9-13]. Gardasil is EMA (European Medicines Agency)-approved for both sexes, while the EMA-approval for Cervarix is currently limited to females only. Gardasil-9 is a newly EMA-approved nonavalent vaccine, which is targeted against HPV types 6, 11, 16, 18, 31, 33, 45, 52 and 58 [14]. It has been shown to be $96.7 \%$ effective against cervical, vaginal and vulvar intraepithelial neoplasia caused by HPV types 31, 33, 45, 52 and 58 [15] when compared to quadrivalent Gardasil [15]. However, high coverage is needed in order to achieve a high efficacy for vaccination programmes. Still, despite a proven efficacy and security profile, the vaccination coverage in Germany is only about 40\% [16]. To achieve a higher coverage, education on HPV, its associated diseases, routes of transmission and possibilities for prevention needs to be expanded. Many young people use electronic media as their primary source of information $[17,18]$. However, there is still a large proportion that gathers their information about medical issues when visiting their doctor. However, when young men are asked about their level of information regarding HPV, over $90 \%$ state that they have never been informed by their primary care physician [19]. Updated knowledge and positive attitude towards the vaccine are shown to be the main determinant factors for recommendation of vaccination among physicians [20,21]. Especially in HPV vaccination, it is well documented that the physician's experience and attitude towards HPV vaccine are major motivators for patients to receive immunization $[16,22]$. We therefore aimed to determine the level of knowledge about HPV and the attitude towards HPV vaccination in obstetricians and gynecologists.

\section{Material and Methods \\ $\nabla$}

\section{Design of the questionnaire}

A self-designed questionnaire containing 42 multiple-choice questions was used.

Part of the questions allowed multiple answers, whereas in some questions there was only one answer possible. A few questions had the option to add a free text answer if desired. Questions were designed according to similar literature already published.

\section{Content of the questionnaire}

The questionnaire was divided into three sections.

The first section containing 11 questions surveyed demographic data of the participants (age, gender, nationality, smoking status, education, working experience).

The second section containing 16 questions focused on the attitude of the participants towards vaccination (own vaccination status, reasons against vaccination) in general and vaccination against HPV for girls and boys in particular.

The third section containing 15 questions was designed as a quiz about HPV and the HPV vaccination in order to evaluate the level of knowledge of the participants concerning these topics (relevant HPV types, HPV-related diseases, risk factors for HPV-related diseases, incidence and prevalence of HPV infection in females and males, details about specific vaccinations).

\section{Process of data collection}

The survey was sent to members of the German Society for Obstetrics and Gynecology (DGGG) as an online questionnaire. The DGGG supported the survey by creating the electronic version of the questionnaire and sending the link for the inquiry via their mailing list to all members. The participants were informed that the survey was part of a scientific study. Participation in the inquiry was anonymous and voluntary. The inquiry was open for participation between November 2015 and February 2016. One reminder was sent out after 1.5 months. Participation was possible only once due to IP address recognition.

\section{Statistics}

An entry mask for data collection and evaluation of the returned questionnaires was created in the program SPSS, version 22 (SPSS Inc., Chicago, IL, USA).

\section{Results \\ $\nabla$}

\section{Demographics}

A total of 998 out of 6567 adressed physicians (15.2\%) agreed to participate in the study and returned the questionnaire. 768 of the participants were female $(77.4 \%)$ and 224 were male (22.6\%), the median age was $41(23-83)$ years. 733 (76.8\%) have children and 929 (93.6\%) have a German nationality. 73 (7.4\%) are active and 105 (10.6\%) were former smokers. The majority of 918 respondents (92.8\%) attended university in Germany. 35 (3.5\%) participants absolved the major part of their residency in private practice, $214(21.6 \%)$ in hospitals with basic care, 245 (24.7\%) in hospitals with specialized care and 478 (48.2\%) in hospitals with maximum care. 208 (21.0\%) are not yet board-certified, whereas 265 (26.7\%) have been board-certified for 0-5 years, 208 (21.0\%) for 5-10 years, 183 (18.5\%) for $10-20$ years and 127 (12.8) for more than 20 years. The majority of $86.2 \%$ indicate a positive attitude towards scientific trials whereas only 9.4\% have a negative attitude towards it. An overview of demographic data is given in $\bullet$ Table 1.

\section{Attitude towards vaccinations including HPV}

The majority of 953 (98.2\%) respondents agree with the STIKO (Ständige Impfkommision = permanent vaccination commission) 
Table 1 Demographic data.

\begin{tabular}{|c|c|}
\hline & Total n (\%) \\
\hline & $998(100.0)$ \\
\hline Median age (years) & 43 \\
\hline \multicolumn{2}{|l|}{ Sex } \\
\hline - Female & $768(77.4)$ \\
\hline - Male & $224(22.6)$ \\
\hline n.a. & 6 \\
\hline \multicolumn{2}{|l|}{ Nationality } \\
\hline - German & $929(93.6)$ \\
\hline - Other & $71(7.2)$ \\
\hline n.a. & 5 \\
\hline \multicolumn{2}{|l|}{ Smoker } \\
\hline D Yes & $73(7.4)$ \\
\hline$>\mathrm{No}$ & $813(82.0)$ \\
\hline - Not anymore & $105(10.6)$ \\
\hline n.a. & 7 \\
\hline \multicolumn{2}{|l|}{ Place of study } \\
\hline - Germany & $918(92.8)$ \\
\hline - Other & $96(9.7)$ \\
\hline n.a. & 9 \\
\hline \multicolumn{2}{|l|}{ Highest academic title } \\
\hline - None & $275(27.7)$ \\
\hline - Dipl. med. & $28(2.8)$ \\
\hline Dr.med. & $627(63.3)$ \\
\hline > PD Dr. med. & $24(2.4)$ \\
\hline - Prof. Dr. med. & $37(3.7)$ \\
\hline n.a. & 7 \\
\hline \multicolumn{2}{|l|}{ Residency } \\
\hline - Private practice & $35(3.5)$ \\
\hline - Hospital with basic care & $214(21.6)$ \\
\hline - Hospital with specialized care & $245(24.7)$ \\
\hline - Hospital with maximum care & $478(48.2)$ \\
\hline - Other & $20(2.0)$ \\
\hline n.a. & 6 \\
\hline \multicolumn{2}{|c|}{ Years passed since board examination } \\
\hline - $0-5$ years & $265(26.7)$ \\
\hline - $5-10$ years & $208(21.0)$ \\
\hline - $10-20$ years & $183(18.5)$ \\
\hline$>>20$ years & $127(12.8)$ \\
\hline - Not yet board-certified & $208(21.0)$ \\
\hline n.a. & 7 \\
\hline \multicolumn{2}{|l|}{ Children } \\
\hline > Yes & $221(23.2)$ \\
\hline$>$ No & $733(76.8)$ \\
\hline n.a. & 44 \\
\hline
\end{tabular}

n. a. = no answer.

recommendations. Consequently, 932 (96.3\%) are partially or completely vaccinated along with these recommendations (HPV excluded) and 924 (98.3\%) would vaccinate their children accordingly. 808 (83.2\%) have not received HPV vaccination for themselves. $21(2.2 \%)$ would decline to vaccinate their own daughter, whereas $75(8.2 \%)$ would not vaccinate their own son against HPV. Of all three vaccines, most participants would use Gardasil, followed by Gardasil-9 and finally Cervarix to vaccinate their children, regardless of their sex. When asked if they actually did vaccinate their daughters against HPV, 198 (21.5\%) used Gardasil, 17 (1.8\%) Cervarix, 321 (34.8\%) did not vaccinate their daughters and 398 (43.1\%) do not have a daughter. 144 (80.9\%) of those who did not or would not vaccinate their daughters argumented that their daughter's age does not lie within the official guide- lines. Three (1.7\%) indicated negative experiences with vaccination as their reason and $3(1.7 \%)$ were afraid of side effects. 489 (52.9\%) did not vaccinate their sons, 375 (40.6\%) do not have a son and 58 (6.3\%) performed HPV vaccination of their son using Gardasil. Of those who answered that they did not vaccinate their sons, the following reasons were named: age not within the recommendations (63.9\%), no cost coverage (23.5\%), HPV-associated diseases mainly affect women (4.2\%), side effects (2.5\%). An overview is given in $\bullet$ Table 2 .

\section{Participants' level of information on HPV}

When asked what diseases were possibly caused by HPV the following answers were given: 922 (99.9\%) cervical cancer, 842 (91.2\%) penile cancer, 835 (90.5\%) anal cancer, 806 (87.3\%) oropharyngeal cancer, 727 (78.8\%) vaginal cancer, 782 (84.7\%) vulvar cancer, 378 (41.0\%) rectal cancer, 355 (38.5\%) esophageal cancer, and 901 (97.6\%) condylomata acuminata. HPV 6 and 11 were correctly indicated as cause for condylomata acuminata by 734 (80.9\%), and 753 (83.0\%), respectively. HPV 16 and 18 were named by 171 (18.9\%) and 173 (19.1\%), respectively, to cause anogenital warts. When asked about possible risk factors associated with HPV-related diseases, more than $85 \%$ correctly identified smoking, promiscuity, immunosuppression and HIV infection. Fewer participants named a low educational level (64\%) and usage of oral contraceptives (43\%) as associated factors. 177 (19.5\%) of respondents believed that after a genital infection with HPV 16 or 18, there is an effective antibody titer either for 10-20 years or even lifelong, whereas 163 (17.9\%) indicated that they do not know an answer to this question. When asked the same question regarding immunity after vaccination instead of infection, 729 (80.1\%) correctly answered that there is an immunity for at least $10-20$ years. Most participants knew that Gardasil is targeted against HPV types 6 (85.0\%), 11 (86.7\%), 16 (96.9\%) and 18 (98.5\%). When asked which types Cervarix is targeted at, about $93 \%$ indicated HPV types 16 or 18 , but also type $6(12.2 \%)$ and type 11 (13.6\%) were named. The same question was asked for Gardasil-9 and only $23.1 \%$ respectively $35.5 \%$ chose the wrong answers HPV type 13 or $35.65 .1 \%$ do not know that Gardasil-9 is EMA-approved for females. 316 (37.6\%) believe that Cervarix is EMA-approved in males, whereas only $162(19.3 \%)$ know that Gardasil-9 is EMA-approved in males. 218 (25.9\%) believe that neither Cervarix nor Gardasil nor Gardasil-9 is EMA-approved. Almost all participants knew that there is a recommendation by the German permanent vaccination commission for Cervarix and Gardasil in girls, whereas $154(17.8 \%)$ believe that it is the same for Gardasil-9. 618 (73.0\%) knew that there is no such recommendation for boys. 403 (46.0\%) respectively 405 (46.2\%) indicate that the STIKO-recommendation is for girls aged 9-14 and 9-17 years. The remaining $68(7.8 \%)$ believe that $12-17$ years is the correct answer to this question. An overview is given in $\odot \mathrm{Ta}$ ble 3 .

\section{Discussion}

$\nabla$

In this study, we aimed to determine the level of knowledge on HPV infection and vaccination as well as the attitude of gynecologists towards HPV vaccination.

Knowledge regarding HPV-associated diseases was high among the participants. Most respondents correctly identified all HPVassociated diseases, even if they were non-gynecological like oropharyngeal cancer (87.3\%). Although almost $20 \%$ believed that 
Table 2 Attitude towards vaccinations (incl. HPV).

\begin{tabular}{|c|c|}
\hline & Total n (\%) \\
\hline & $998(100.0)$ \\
\hline \multicolumn{2}{|l|}{ My willingness to participate in clinical trials as a doctor is: } \\
\hline - Absolutely positive & $371(37.4)$ \\
\hline - Rather positive & $485(48.8)$ \\
\hline - Rather negative & $88(8.9)$ \\
\hline D Absolutely negative & $5(0.5)$ \\
\hline - Idon't know & $44(4.4)$ \\
\hline n.a. & 5 \\
\hline \multicolumn{2}{|l|}{ My attitude towards the STIKO-recommendations is: } \\
\hline - Absolutely positive & $718(74.0)$ \\
\hline - Rather positive & $235(24.2)$ \\
\hline - Rather negative & $12(1.2)$ \\
\hline - Absolutely negative & $1(0.1)$ \\
\hline - Idon't know & $4(0.4)$ \\
\hline n.a. & 28 \\
\hline \multicolumn{2}{|l|}{$\begin{array}{l}\text { I am vaccinated according to the STIKO-recommendations } \\
\text { (HPV excluded): }\end{array}$} \\
\hline - Yes, completely & $809(83.6)$ \\
\hline - Yes, partially & $123(12.7)$ \\
\hline - Idon't know & $23(2.4)$ \\
\hline - No, because... & $13(1.3)$ \\
\hline n.a. & 30 \\
\hline \multicolumn{2}{|l|}{ I have received a HPV vaccination for myself: } \\
\hline - No & $808(83.2)$ \\
\hline - Yes, with Gardasil & $135(13.9)$ \\
\hline - Yes, with Cervarix & $24(2.5)$ \\
\hline - Yes, with Gardasil-9 & $1(0.1)$ \\
\hline - Yes, with: other & $3(0.3)$ \\
\hline n.a. & 27 \\
\hline \multicolumn{2}{|l|}{ I counsel female patients on HPV vaccination: } \\
\hline$\checkmark$ Yes & $850(87.8)$ \\
\hline - No & $118(12.2)$ \\
\hline n.a. & 30 \\
\hline \multicolumn{2}{|l|}{$\begin{array}{l}\text { I perform HPV vaccination in female patients } \\
\text { (multiple answers possible): }\end{array}$} \\
\hline - Yes, with Gardasil & $384(39.6)$ \\
\hline - Yes, with Cervarix & $38(3.9)$ \\
\hline - Yes, with Cervarix and Gardasil & $173(17.9)$ \\
\hline - Yes, with Gardasil-9 & $22(2.3)$ \\
\hline - No, because: there is no demand & $131(13.5)$ \\
\hline - No, because: fear of side effects & $1(0.1)$ \\
\hline - No, because ... (free text) & $291(30.0)$ \\
\hline n.a. & 29 \\
\hline \multicolumn{2}{|l|}{ I counsel male patients on HPV vaccination: } \\
\hline > Yes & $151(15.7)$ \\
\hline - No & $809(84.3)$ \\
\hline n.a. & 38 \\
\hline \multicolumn{2}{|l|}{$\begin{array}{l}\text { I perform HPV vaccination in male patients } \\
\text { (multiple answers possible): }\end{array}$} \\
\hline - Yes, with Gardasil & $31(3.2)$ \\
\hline - Yes, with Gardasil-9 & $7(0.7)$ \\
\hline - No, because: there is no demand & $139(14.4)$ \\
\hline - No, because: vaccinating women is sufficient & $2(0.2)$ \\
\hline - No, because: health insurance does not bear the costs & $62(6.4)$ \\
\hline $\begin{array}{l}\text { No, because: HPV vaccination for men is medically not } \\
\text { advisable }\end{array}$ & $3(0.3)$ \\
\hline - No, because: fear of side effects from medical perspective & $0(0.0)$ \\
\hline - No, because: gynecologist & $734(76.2)$ \\
\hline - No, because... & $97(10.1)$ \\
\hline n.a. & 35 \\
\hline
\end{tabular}

Table 2 Attitude towards vaccinations (incl. HPV). (Continued)

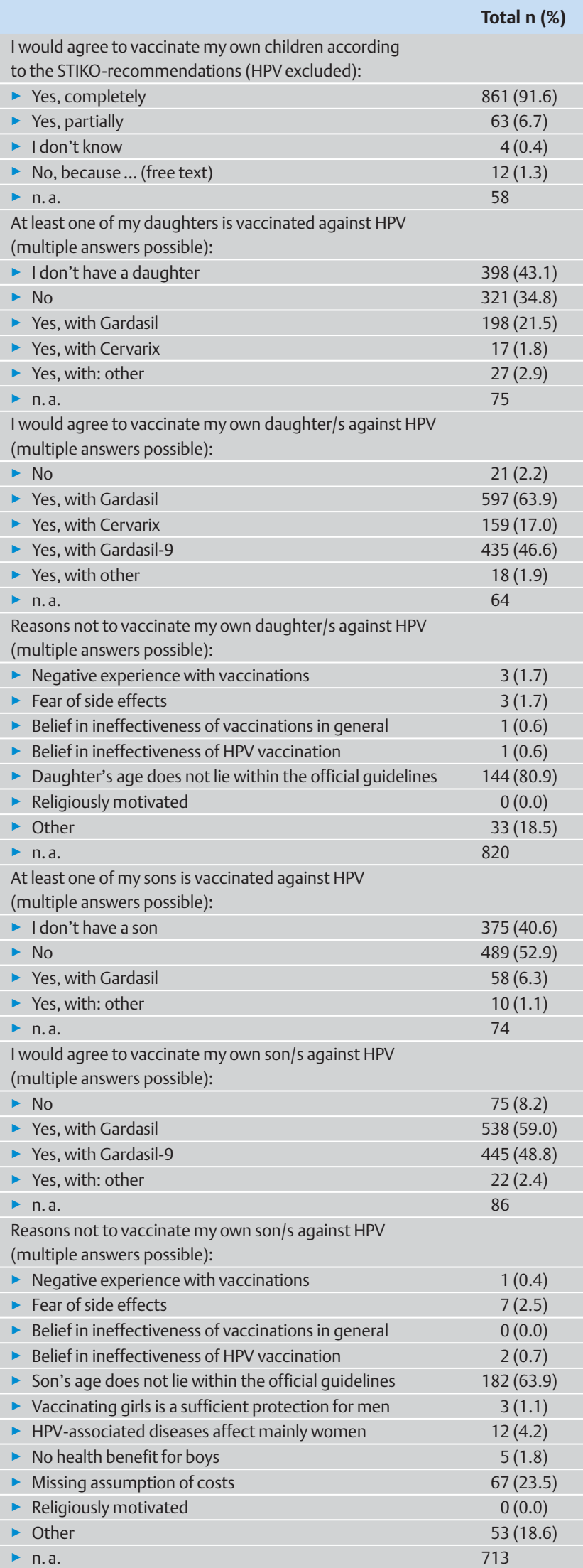

n. a. = no answer; STIKO: Ständige Impfkommission (permanent vaccination commission of Germany). 
Table 3 Participants' level of information on HPV.

\begin{tabular}{|c|c|}
\hline & Total n (\%) \\
\hline & $998(100.0)$ \\
\hline \multicolumn{2}{|l|}{ Which diseases are HPV-associated? } \\
\hline - Cervical cancer & $922(99.9)$ \\
\hline - Penile cancer & $842(91.2)$ \\
\hline Anal cancer & $835(90.5)$ \\
\hline - Oropharyngeal cancer & $806(87.3)$ \\
\hline - Vaginal cancer & $727(78.8)$ \\
\hline Vulvar cancer & $782(84.7)$ \\
\hline - Rectal cancer & $378(41.0)$ \\
\hline - Esophageal cancer & $355(38.5)$ \\
\hline - Condylomata acuminata & $901(97.6)$ \\
\hline n.a. & 75 \\
\hline \multicolumn{2}{|l|}{ Which HPV types typically cause condylomata acuminata? } \\
\hline - 6 & $734(80.9)$ \\
\hline > 11 & $753(83.0)$ \\
\hline > 13 & $79(8.7)$ \\
\hline > 16 & $171(18.9)$ \\
\hline - 18 & $173(19.1)$ \\
\hline - 31 & $65(7.2)$ \\
\hline - 45 & $47(5.2)$ \\
\hline > n.a. & 91 \\
\hline \multicolumn{2}{|l|}{ What are typical risk factors for HPV-associated diseases? } \\
\hline Smoking & $797(86.6)$ \\
\hline Promiscuity & $893(97.1)$ \\
\hline - Usage of the contraceptive pill & $394(42.8)$ \\
\hline - Low educational level & $590(64.1)$ \\
\hline - Immunosuppression & $841(91.4)$ \\
\hline - HIV infection & $806(87.6)$ \\
\hline n.a. & 78 \\
\hline \multicolumn{2}{|l|}{$\begin{array}{l}\text { Is there an effective antibody titer after a genital infection } \\
\text { with HPV } 16 \text { or } 18 \text { ? }\end{array}$} \\
\hline - No effective antibody titer & $530(58.2)$ \\
\hline - Effective antibody titer for approximately $1-2$ years & $40(4.4)$ \\
\hline - Effective antibody titer for approximately $10-20$ years & $107(11.8)$ \\
\hline - Longlife immunity & $70(7.7)$ \\
\hline - I don't know & $163(17.9)$ \\
\hline n.a. & 88 \\
\hline \multicolumn{2}{|l|}{$\begin{array}{l}\text { Is there an effective antibody titer after vaccination } \\
\text { against HPV } 16 \text { or } 18 \text { ? }\end{array}$} \\
\hline - Effective antibody titer for approximately $1-2$ years & $15(1.7)$ \\
\hline - Effective antibody titer for approximately 5-7 years & $163(18.0)$ \\
\hline - Effective antibody titer for at least $10-20$ years & $729(80.4)$ \\
\hline n.a. & 91 \\
\hline \multicolumn{2}{|l|}{ Incidence of HPV infection is... } \\
\hline Higher in women & $379(41.6)$ \\
\hline - Higher in men & $40(4.4)$ \\
\hline - Equivalent in men and women & $380(41.7)$ \\
\hline - Idon't know & $112(12.3)$ \\
\hline n.a. & 87 \\
\hline \multicolumn{2}{|l|}{ Prevalence of HPV infection is... } \\
\hline - Higher in women & $419(45.9)$ \\
\hline - Higher in men & $31(3.4)$ \\
\hline - Equivalent in men and women & $309(33.8)$ \\
\hline I don't know & $154(16.9)$ \\
\hline n.a. & 85 \\
\hline \multicolumn{2}{|l|}{ Gardasil is targeted against HPV type... } \\
\hline$>6$ & $734(85.0)$ \\
\hline > 11 & $749(86.7)$ \\
\hline > 13 & $60(6.9)$ \\
\hline > 16 & $837(96.9)$ \\
\hline > 18 & $851(98.5)$ \\
\hline - 31 & $65(7.5)$ \\
\hline - 33 & $47(5.4)$ \\
\hline
\end{tabular}

Table 3 Participants' level of information on HPV. (Continued)

\begin{tabular}{|c|c|}
\hline & Total n (\%) \\
\hline - 35 & $15(1.7)$ \\
\hline - 45 & $32(3.7)$ \\
\hline > 52 & $12(1.4)$ \\
\hline - 58 & $8(0.9)$ \\
\hline n.a. & 134 \\
\hline \multicolumn{2}{|c|}{ Cervarix is targeted against HPV type... } \\
\hline$>6$ & $102(12.2)$ \\
\hline > 11 & $113(13.5)$ \\
\hline - 13 & $30(3.6)$ \\
\hline > 16 & $778(93.3)$ \\
\hline > 18 & $783(93.9)$ \\
\hline - 31 & $40(4.8)$ \\
\hline - 33 & $39(4.7)$ \\
\hline - 35 & $18(2.2)$ \\
\hline > 45 & $34(4.1)$ \\
\hline > 52 & $6(0.7)$ \\
\hline - 58 & $4(0.5)$ \\
\hline n.a. & 164 \\
\hline \multicolumn{2}{|c|}{ Gardasil-9 is targeted against HPV type ... } \\
\hline - 6 & $702(92.0)$ \\
\hline > 11 & $708(92.8)$ \\
\hline > 13 & $176(23.1)$ \\
\hline > 16 & $750(98.3)$ \\
\hline > 18 & $756(99.1)$ \\
\hline - 31 & $561(73.5)$ \\
\hline - 33 & $580(76.0)$ \\
\hline > 35 & $271(35.5)$ \\
\hline > 45 & $558(73.1)$ \\
\hline$>52$ & $460(60.3)$ \\
\hline > 58 & $366(48.0)$ \\
\hline n.a. & 235 \\
\hline \multicolumn{2}{|c|}{ EMA-approval in females exists for ... } \\
\hline - Cervarix & $846(97.1)$ \\
\hline - Gardasil & $865(99.3)$ \\
\hline - Gardasil-9 & $304(34.9)$ \\
\hline D None & $0(0.0)$ \\
\hline n.a. & 127 \\
\hline \multicolumn{2}{|c|}{ EMA-approval in males exists for... } \\
\hline - Cervarix & $316(37.6)$ \\
\hline - Gardasil & $603(71.7)$ \\
\hline - Gardasil-9 & $162(19.3)$ \\
\hline - None & $218(25.9)$ \\
\hline n.a. & 157 \\
\hline \multicolumn{2}{|c|}{ STIKO-recommendation for females exists for ... } \\
\hline - Cervarix & $784(90.8)$ \\
\hline - Gardasil & $842(97.6)$ \\
\hline - Gardasil-9 & $154(17.8)$ \\
\hline - None & $6(0.7)$ \\
\hline > n.a. & 135 \\
\hline \multicolumn{2}{|c|}{ STIKO-recommendation for males exists for ... } \\
\hline - Cervarix & $110(13.0)$ \\
\hline - Gardasil & $212(25.0)$ \\
\hline - Gardasil-9 & $42(5.0)$ \\
\hline - None & $618(73.0)$ \\
\hline n.a. & 151 \\
\hline \multicolumn{2}{|c|}{ HPV vaccination for girls is recommended by the STIKO ... } \\
\hline Between the age of 9-14 & $403(46.0)$ \\
\hline Between the age of 9-17 & $405(46.2)$ \\
\hline - Between the age of $12-17$ & $68(7.8)$ \\
\hline n.a. & 122 \\
\hline
\end{tabular}

EMA: European Medicines Agency; STIKO: Ständige Impfkommission (Permanent vaccination commission of Germany); n. a. = no answer. 
genital warts were caused by high-risk HPV types 16 and 18, the majority of more than $80 \%$ identified types 6 and 11 as the correct answers. Typical risk factors like smoking, promiscuity, immunosuppression and HIV infection were named correctly by more than $85 \%$, but only $43 \%$ knew that a low educational level is a risk factor, too. Still, compared to similar surveys, the level of information regarding HPV infection is high $[23,24]$. A study in the United Kingdom showed that up to 55\% of respondents had a lack of knowledge about the etiology of cervical cancer [25]. One of the reasons for this discrepancy could be that most surveys were performed among pediatricians and family care doctors in addition to gynecologists instead of gynecologists alone. Compared to these two subspecialities, gynecologists are more often confronted with the consequences of HPV infection, such as genital warts or cervical cancer. In contrast, vaccinations are typically performed at the office of pediatricians or general practitioners, so the question arose, how much knowledge gynecologists do have on HPV vaccination. On the one hand most participants knew which HPV types are targeted by Gardasil and Cervarix, and even Gardasil-9, which was EMA-approved only in 2015, is already well-known. On the other hand, more than a third of the participants were not informed properly about an effective antibody titer after HPV infection; almost $20 \%$ of the respondents wrongly believe that there is an effective antibody titer either for 10-20 years or even lifelong after an HPV infection with types 16 or 18 , whereas additional $18 \%$ indicate that they do not know the answer. In fact, around $50 \%$ of women do not develop an antibody response after natural infection and in those who do, the extent and the duration of protection against HPV infection is still unknown $[26,27]$. These findings could indicate that there is no effective natural immunity after HPV infection and emphasize the necessity of HPV vaccination even for women who already experienced HPV infection.

In awareness of the known low HPV vaccination coverage rate in girls, vaccinating boys could represent an additional option to optimize protection for women, too. Vaccinating boys is effective and could also help to reduce HPV-associated disease burden in males [28]. Interestingly, only $8.2 \%$ of respondents refused to vaccinate their sons against HPV compared to $2.2 \%$ in daughters. However, 52.9 vs. $34.8 \%$ did not vaccinate their sons respectively their daughters. The main reason besides the fact that the age of their children did not fit into the age recommendations, was with $23.5 \%$ the missing cost coverage for males. Additionally, $4.2 \%$ think that HPV vaccination in males is not necessary since associated diseases mainly affect women. Presently, in Germany there is a STIKO vaccination recommendation regarding HPV for girls aged 9-14 years only. Men are excluded from this recommendation and therefore vaccination is not covered by general insurance. In contrast, Australia, Canada, Austria and the USA already have guidelines that recommend vaccination in boys, too [2932]. The decision if HPV vaccination should also be recommended for boys needs a thorough cost-benefit analysis. Previous modeling studies have shown that in case of high vaccination coverage of girls, sufficient protection for boys would be generated, too [33].

However, coverage in Germany is low which could partially be attributed to the lack of school-based vaccination programs. In order to achieve higher protection for girls, vaccinating boys could represent a useful supplement that would also help decrease the disease burden in men, too. Since recent analyses showed that depending on the age of patients also two doses of vaccine provide sufficient immune response, re-calculation regarding cost efficacy for HPV vaccination in men needs to be done. Still, irrespective of a possible cost coverage of HPV vaccination by health insurances, counseling also male patients about the disease as well as possible ways of protection is crucial to further decrease HPV-associated disease burden. Especially young people gather their information about health-related topics oftentimes through the internet $[17,18]$. Unfortunately, electronic media is frequently not monitored for correctness and sometimes failes to provide reliable and transparent information [34]. One way to overcome this difficulty could be the introduction of certain standards that might help readers to identify correct and reliable sources. In addition, the discussion abouth health topics with their primary physician is irreplaceable. However, gynecologists only rarely counsel male patients during their daily work-routine. Besides general practitioners mostly pediatricians get in touch with young men and get the chance to discuss the issue of HPV vaccination with them. Therefore, a similar survey performed among pediatricians would be highly valuable.

\section{Conclusion \\ $\nabla$}

In conclusion this inquiry demonstrates that gynecologists in Germany are very well informed about HPV and available HPV vaccines. Furthermore, there is a very positive attitude of these specialists towards the vaccination against HPV, even in males. However, sons of gynecologists are only rarely vaccinated against HPV, mainly due to the lack of cost coverage. Vaccinating boys could not only decrease the disease burden in males, but also protect women by interrupting ways of transmission. In light of the fact that vaccination coverage in Germany is low, alternatives to increase protection need to be evaluated. One possible option represents vaccination of males, which is performed already by several countries. This survey showed that the main argument of gynecologists against vaccination of boys is only of financial and not of medical nature. However, the necessity of a vaccination recommendation for boys needs to be re-evaluated taking into account the cost-reduced 2-dose vaccination scheme.

\section{Note}

$\nabla$

This publication is part of the dissertation of Karin Baltateanu.

\section{Acknowledgements}

\section{$\nabla$}

We would like to thank the German Society for Gynecology and Obstetrics (DGGG) and its president Prof. Diethelm Wallwiener for their support of this inquiry. We thank in particular Yvonne Stiegeler for her assistance.

\section{Conflict of Interest \\ $\nabla$}

Mahner, S.: Research support, Advisory Board, Honoraria, Travel support from: AstraZeneca, Bayer, Boehringer Ingelheim, Jenapharm, GSK, JanssenCilag, Medac, MSD, Pharmamar, Roche, Tesaro, Teva. Dannecker, C.: Honoraria from Sanofi-MSD and GSK. All other authors declare no conflicts of interest. 


\section{References}

1 Trottier H, Franco EL. The epidemiology of genital human papillomavirus infection. Vaccine 2006; 24 (Suppl. 1): S1-S15

2 Varma S, Lathrop E, Haddad LB. Pediatric condyloma acuminata. J Pediatr Adolesc Gynecol 2013; 26: e121-e122

3 Forman D, de Martel C, Lacey CJ et al. Global burden of human papillomavirus and related diseases. Vaccine 2012; 30 (Suppl. 5): F12-F23

4 International Agency for Research on Cancer. Human Papillomaviruses. IARC Monographs on the Evaluation of carcinogenic Risks to Humans. Volume 90. Lyon, France: WHO press; 2007

5 Munoz N, Bosch FX, de Sanjose S et al. Epidemiologic classification of human papillomavirus types associated with cervical cancer. N Engl J Med 2003; 348: 518-527

6 Kim KS, Park SA, Ko KN et al. Current status of human papillomavirus vaccines. Clin Exp Vaccine Res 2014; 3: 168-175

7 Walboomers JM, Jacobs MV, Manos MM et al. Human papillomavirus is a necessary cause of invasive cervical cancer worldwide. J Pathol 1999; 189: $12-19$

8 Workowski KA, Berman SM. Sexually transmitted diseases treatment guidelines, 2006. MMWR Recomm Rep 2006; 55: 1-94

9 Villa LL, Costa RL, Petta CA et al. Prophylactic quadrivalent human papillomavirus (types 6,11,16, and 18) L1 virus-like particle vaccine in young women: a randomised double-blind placebo-controlled multicentre phase II efficacy trial. Lancet Oncol 2005; 6: 271-278

10 Villa LL, Costa RL, Petta CA et al. High sustained efficacy of a prophylactic quadrivalent human papillomavirus types 6/11/16/18 L1 virus-like particle vaccine through 5 years of follow-up. Br J Cancer 2006; 95: 1459-1466

11 Harper DM, Franco EL, Wheeler C et al. Efficacy of a bivalent L1 viruslike particle vaccine in prevention of infection with human papillomavirus types 16 and 18 in young women: a randomised controlled trial. Lancet 2004; 364: 1757-1765

12 Harper DM, Franco EL, Wheeler CM et al. Sustained efficacy up to 4.5 years of a bivalent L1 virus-like particle vaccine against human papillomavirus types 16 and 18: follow-up from a randomised control trial. Lancet 2006; 367: 1247-1255

13 Saslow D, Boetes C, Burke W et al. American Cancer Society guidelines for breast screening with MRI as an adjunct to mammography. CA Cancer J Clin 2007; 57: 75-89

14 Kirby T. FDA approves new upgraded Gardasil 9. Lancet Oncol 2015; 16: e56

15 Joura EA, Giuliano AR, Iversen OE et al. A 9-valent HPV vaccine against infection and intraepithelial neoplasia in women. N Engl J Med 2015; 372: 711-723

16 Ogilvie GS, Remple VP, Marra F et al. Parental intention to have daughters receive the human papillomavirus vaccine. CMAJ 2007; 177: $1506-1512$

17 Hesse BW, Nelson DE, Kreps GL et al. Trust and sources of health information: the impact of the Internet and its implications for health care providers: findings from the first Health Information National Trends Survey. Arch Intern Med 2005; 165: 2618-2624

18 Gray NJ, Klein JD, Noyce PR et al. Health information-seeking behaviour in adolescence: the place of the internet. Soc Sci Med 2005; 60: 14671478
19 Schwarz TM, Honsberg T, Stephan $N$ et al. HPV vaccination: acceptance and influencing factors among young men in Germany. Future Microbiol 2016; 11: 227-234

20 Zimet GD, Mays RM, Fortenberry JD. Vaccines against sexually transmitted infections: promise and problems of the magic bullets for prevention and control. Sex Transm Dis 2000; 27: 49-52

21 Riedesel JM, Rosenthal SL, Zimet GD et al. Attitudes about human papillomavirus vaccine among family physicians. J Pediatr Adolesc Gynecol 2005; 18: 391-398

22 Gerend MA, Lee SC, Shepherd JE. Predictors of human papillomavirus vaccination acceptability among underserved women. Sex Transm Dis 2007; 34: 468-471

23 Tolunay 0, Celik U, Karaman SS et al. Awareness and attitude relating to the human papilloma virus and its vaccines among pediatrics, obstetrics and gynecology specialists in Turkey. Asian Pac J Cancer Prev 2014; 15: $10723-10728$

24 Wong MC, Lee A, Ngai KL et al. Knowledge, attitude, practice and barriers on vaccination against human papillomavirus infection: a crosssectional study among primary care physicians in Hong Kong. PLoS One 2013; 8: e71827

25 Hopkins TG, Wood NJ, West RM et al. UK health professionals' attitudes and knowledge regarding Human Papillomavirus (HPV) vaccination: a West Yorkshire Study. J Paediatr Child Health 2009; 45: 652-655

26 Schwarz TF, Leo 0 . Immune response to human papillomavirus after prophylactic vaccination with AS04-adjuvanted HPV-16/18 vaccine: improving upon nature. Gynecol Oncol 2008; 110: S1-S10

27 Carter JJ, Koutsky LA, Hughes JP et al. Comparison of human papillomavirus types 16,18 , and 6 capsid antibody responses following incident infection. J Infect Dis 2000; 181: 1911-1919

28 Giuliano AR, Palefsky JM, Goldstone S et al. Efficacy of quadrivalent HPV vaccine against HPV Infection and disease in males. N Engl J Med 2011; 364: 401-411

29 Centers for Disease Control and Prevention (CDC). Recommendations on the use of quadrivalent human papillomavirus vaccine in males-Advisory Committee on Immmunization Practices (ACIP), 2011. MMWR Morb Mortal Wkly Rep 2011; 60: 1705-1708

30 Australian Government Department of Health. Pharmaceutical Benefits Advisory Committee: Outcomes - Positive Recommendations. 2011. Online: http://www.pbs.gov.au/info/industry/listing/elements/ pbac-meetings/pbac-outcomes/2011-11/positive-recommendations; last access: 23.07.2016

31 An Advisory Committee Statement (ACS), National Advisory Committee on Immunization (NACI): Update On Human Papillomavirus (HPV) Vaccines. Canada communicable disease report 2012; 38. Online: http://www.phac-aspc.gc.ca/publicat/ccdr-rmtc/12vol38/acs-dcc-1/ index-eng.php; last access: 23.07.2016

32 Eurosurveillance editorial team. Updated version of ECDC guidance on human papillomavirus vaccines in Europe available. Euro Surveill 2012; 17: 20274

33 Brisson $M$, van de Velde $N$, Franco EL et al. Incremental impact of adding boys to current human papillomavirus vaccination programs: role of herd immunity. J Infect Dis 2011; 204: 372-376

34 Bodemer N, Müller SM, Okan Y et al. Do the media provide transparent health information? A cross-cultural comparison of public information about the HPV vaccine. Vaccine 2012; 30: 3747-3756 